\title{
Peningkatan Keterampilan Menulis Rangkuman Menggunakan Model Cooperative Integrated Reading And Composition Kelas VII B SMP Negeri 8 Singkawang Tahun Pelajaran 2015/2016
}

\author{
Suyudi $^{1)}$, Mardian ${ }^{2)}$, Wahyuni Oktavia ${ }^{3)}$ \\ Program Studi Pendidikan Bahasa dan Sastra Indonesia, STKIP Singkawang, \\ Email: suyudinova@gmail.com
}

\begin{abstract}
Abstrak. Penelitian ini dilatar belakangi oleh rendahnya nilai menulis siswa. Hal ini dikarenakan materi menulis sulit dikuasai, siswa kurang memberikan respon positif terhadap kegiatan menulis sehingga siswa kesulitan dalam mencapai tujuan dalam memahami pesan yang ingin pengarang sampaikan melalui tulisan. Selanjutnya penelitian ini difokuskan pada materi menulis rangkuman menggunakan model cooperative integrated reading and composition composition pada materi menulis rangkuman yang menemukan pokok-pokok isi buku dan mampu merangkai isi buku menjadi rangkuman. Berdasarkan uraian diatas, rumusan masalah dalam penelitian ini adalah bagaimanakah perencanaan, pelaksanaan, dan hasil dari pembelajaran menulis rangkuman menggunakan model cooperative integrated reading and composition. Model penelitian ini adalah deskriftif dengan bentuk kualitatif. Bentuk penelitian ini adalah penelitian tindakan kelas atau clasroom action, yaitu untuk memecahkan masalah dalam pembelajaran secara bersiklus. Setiap siklus terdiri dari empat tahap yaitu tahap perencanaan, pelaksanaan, observasi dan refleksi. Data dari penelitian ini adalah aktivitas guru dan siswa dalam pembelajaran menulis rangkuman kelas VIII B SMP Negeri 8 Singkawang. Hasil penelitian tindakan kelas ini sebelum dilakukan tindakan nilai rata-rata siswa $41,17 \%$. Setelah dilakukan tindakan siklus I adanya peningkatan menjadi $64,70 \%$, sedangkan pada siklus II ketuntasan mencapai $87,87 \%$. Berdasarkan penelitian ini guru sebaiknya menggunakan model pembelajaran yang dapat meningkatkan kemampuan siswa terhadap menulis, dalam pemilihan model pembelajaran disesuaikan dengan karakteristik siswa. Dengan demikian, dapat disimpulkan bahwa pelaksanaan pembelajaran materi menulis rangkuman dengan menggunakan model cooperative integrated reading and composition pada kelas VIII B SMP Negeri 8 Singkawang dapat meningkat.
\end{abstract}

Kata Kunci : kemampuan menulis, rangkuman, cooperative integrated reading and composition.

\section{PENDAHULUAN}

Keterampilan berbahasa erat kaitannya dengan proses yang mendasari bahasa, bahasa merupakan cerminan pikiran, semakin terampil seseorang berbahasa semakin cerah dan jelas pula jalan pikirannya. Keterampilan hanya dapat diperoleh dan dikuasai dengan jalan praktik dan banyak latihan. Melatih keterampilan berbahasa berarti juga melatih keterampilan berpikir [6]. Melatih keterampilan berbahasa berarti juga melatih keterampilan berpikir [9].

Keterampilan berbahasa mencakup empat aspek, yaitu keterampilan menyimak, keterampilan berbicara, keterampilan membaca dan keterampilan menulis. Setiap keterampilan erat sekali berhubungan dengan tiga keterampilan lainnya dengan cara yang beraneka ragam. Dalam memperoleh keterampilan berbahasa, kita biasanya melalui suatu hubungan yang teratur. Pertama pada masa kecil kita belajar menyimak bahasa, kemudian berbicara, setelah itu kita belajar membaca dan menulis. Menyimak dan berbicara sudah kita pelajari sebelum masuk sekolah. Keempat keterampilan tersebut pada dasarnya merupakan suatu kesatuan dalam aspek berbahasa.

Menulis dapat diartikan sebagai kegiatan menuangkan ide/gagasan dengan menggunakan bahasa tulis sebagai media penyampai [1].
Berdasarkan masalah tersebut, peneliti ingin melakukan penelitian untuk meningkatkan keterampilan menulis siswa kelas VIII B, pada materi menulis rangkuman. Alasan peneliti memilih menulis rangkuman karena materi ini berhubungan dengan pemahaman siswa dalam menulis sebuah informasi yang ditulis hanya pokok-pokok informasinya, jadi pada materi ini akan menarik minat siswa, sehingga keterampilan menulis dapat ditingkatkan. Pemilihan kelas VIII B karena rendahnya nilai siswa pada materi menulis rangkuman masih belum mencapai kriteria ketuntasan minimal (KKM).

Berdasarkan identifikasi masalah tersebut maka masalah umum dalam penelitian ini adalah "Bagaimanakah Peningkatan Keterampilan Menulis Rangkuman Menggunakan Model Pembelajaran Cooperative Integrated Reading and Composition Kelas VIII B SMP Negeri 8 Singkawang Tahun Pelajaran 2015/2016". Adapun sub-sub masalah yang akan dirumuskan dalam penelitian ini adalah (1) Bagaimanakah perencanaan pembelajaran keterampilan menulis rangkuman menggunakan Model Pembelajaran Cooperative Integrated Reading and Composition Kelas VIII B SMP Negeri 8 Singkawang Tahun Pelajaran 2015/2016? (2) Bagaimanakah pelaksanaan pembelajaran keterampilan menulis rangkuman menggunakan Model Pembelajaran Cooperative Integrated Reading and 
Composition Kelas VIII B SMP Negeri 8 Singkawang Tahun Pelajaran 2015/2016? (3) Bagaimanakah hasil pembelajaran keterampilan menulis rangkuman menggunakan Model Pembelajaran Cooperative Integrated Reading and Composition Kelas VIII B SMP Negeri 8 Singkawang Tahun Pelajaran 2015/2016? tujuan penelitian ini adalah (1) Pendeskripsikan perencanaan pembelajaran keterampilan menulis rangkuman menggunakan Model Pembelajaran Cooperative Integrated Reading and Composition Kelas VIII B SMP Negeri 8 Singkawang Tahun Pelajaran 2015/2016. (2) Pendeskripsikan pelaksanaan pembelajaran keterampilan menulis rangkuman menggunakan Model Pembelajaran Cooperative Integrated Reading and Composition Kelas VIII B SMP Negeri 8 Singkawang Tahun Pelajaran 2015/2016. (3) Pendeskripsikan hasil pembelajaran keterampilan menulis rangkuman menggunakan Model Pembelajaran Cooperative Integrated Reading and Composition Kelas VIII B SMP Negeri 8 Singkawang Tahun Pelajaran 2015/2016.

Menulis adalah suatu keterampilan berbahasa yang dipergunakan untuk be rkomunikasi secara tidak langsung, tidak secara tatap muka dengan orang lain [4]. Rangkuman adalah cara yang paling efektif untuk menyajikan sebuah wacana yang panjang dalam bentuk singkat. [2]. Model kooperatif adalah solusi ideal terhadap masalah menyediakan kesempatan berinteraksi seara kooperatif dan tidak dangkal kepada para siswa dari latar belakang dan etnik yang berbeda [5]. Pembelajaran kooperatif merupakan bentuk pembelajaran dengan cara siswa belajar dan bekerja dalam kelompok kecil secara kolaboratif yang anggotanya terdiri dari empat sampai enam orang dengan struktur kelompok yang bersifat heterogen [3]. Setiap kelompok diberikan kesempatan untuk bertemu muka dengan kegiatan diskusi. Kegiatan interaksi ini akan memberi siswa bentuk sinergi yang menguntungkan semua anggota. Guru menjadwalkan waktu bagi kelompok untuk mengevaluasi proses kerja kelompok dah hasil kerjasama mereka agar selanjutnya bisa bekerja lebih efektif. Pembelajaran kooperatif mewadahi bagaimana siswa dapat bekerjasama dalam kelompok, tujuan kelompok adalah tujuan bersama. Situasi kooperatif merupakan bagian dari siswa untuk mencapai tujuan kelompok, siswa harus merasakan bahwa mereka akan mencapai tujuan, maka siswa lain dalam kelompoknya memiliki kebersamaan, artinya setiap anggota kelompok harus bersikap kooperatif dengan sesama anggota kelompoknya.

Perencanaan pembelajaran adalah rencana yang harus dilakukan oleh guru sebelum melaksanakan kegiatan belajar mengajar untuk mencapai tujuan pembelajaran yang akan dicapai.Perlunyan perencanaan pembelajaran sebagaimana disebutkan di atas dimaksudkan agar dapat perbaikan pembelajaran.

Hasil belajar dalam penelitian tindakan kelas ini dimaksudkan adalah hasil penilaian yang mengacu pada tujuan pembelajaran yang terdapat pada rencana pelaksanaan pembelajaran. Penilaian dilakukan setelah siswa mengikuti langkah-langkah pembelajaran.Penilaian dilakukan setelah siswa mengikuti langkah-langkah pembelajaran yang sudah direncanakan satu kali pertemuan.

\section{METODE}

Tempat penelitian tindakan kelas ini dilaksanakan di SMP Negeri 8 Singkawang mata pelajaran bahasa Indonesia kelas VIII B. Penelitian ini dilaksanakan pada tanggal 6 April - 14 April 2016. Kolaborator dalam penelitian ini adalah guru mata pelajaran bahasa Indonesia yang mengajar di kelas VIII B, yaitu Suryati, S. Pd. Metode yang digunakan dalam rencana penelitian ini adalah metode deskriptif. [8] mengungkapkan bahwa "Deskriptif artinya data terurai dalam bentuk kata-kata atau gambar-gambar bukan dalam bentuk angka-angka". Bentuk penelitian ini adalah penelitian kualitatif. Penelitian kualitatif adalah penelitian yang menghasilkan prosedur analisis yang tidak menggunakan prosedur analisis statistik atau cara kuantifikasi lainnya [2]. Bentuk penelitian yang digunakan dalam penelitian ini adalah kualitatif. Rancangan penelitian ini dilakukan dalam bentuk Penelitian Tindakan Kelas (PTK). [9] mengatakan bahwa: Penelitian Tindakan Kelas (PTK) adalah suatu kegiatan penelitian ilmiah yang dilakukan secara rasional, sistematis dan empiris reflektif terhadap berbagai tindakan yang dilakukan oleh guru atau dosen (tenaga pendidik), kolaborasi (tim peneliti) yang sekaligus sebagai peneliti, sejak disusunnya suatu perencanaan sampai penilaian terhadap tindakan nyata di dalam kelas yang berupa kegiatan belajar-mengajar, untuk memperbaiki dan meningkatkan kondisi pembelajaran yang dilakukan. Sumber data dalam penelitian ini adalah guru dan siswa. Adapun data yang diperoleh dalam penelitian ini adalah penilaian proses dan hasil. Teknik pengumpul data merupakan suatu cara yang dilakukan peneliti untuk memperoleh data. Tanpa mengetahui teknik pengumpul data, maka peneliti tidak akan mendapatkan data yang memenuhi standar data yang diharapkan".Untuk memperoleh data dalam penelitian ini, peneliti menggunakan teknik pengumpul sebagai berikut, (1) Teknik Observasi Langsung, (2) Teknik Pengukuran, (3) Teknik Komunikasi Langsung. Alat pengumpul data yang digunakan dalam rencana penelitian ini yaitu lembar observasi, APKG I, APKG II, lembar pengamatan sikap, tes, wawancara. Teknik analisis data yang digunakan dalam rencana penelitian ini yaitu perencanaan dinilai menggunakan APKG I, pelaksanaan dinilai menggunakan APKG II, dan hasil pembelajaran dianalisis dengan melakukan penilaian proses dan hasil.

\section{HASIL DAN PEMBAHASAN}

HASIL

\section{Perencanaan Peningkatan Keterampilan Menulis Rangkuman Menggunakan Model Cooperative Integrated Reading and Composition Siklus I}

Pada tahap perencanaan dalam kegiatan pembeajaran menulis rangkuman peneiti dan kolaborator saling bekerja sama untuk menyusun kegiatan proses belajar mengajar yang akan dilaksanakan pada tanggal 3-4 April 2016. Pada 
tahap ini peneliti dan kolaborator merencanakan kegiatan pembelajaran.

\section{Pelaksanaan Peningkatan Keterampilan Menulis Rangkuman Menggunakan Model Cooperative Integrated Reading and Composition Siklus I}

1. Perencanaan (Planing)

Perencanaan merupakan unsur terpenting dalam persiapan pembelajaran, perencanaan dalam arti yang sederhana dapat dijelaskan sebagai suatu proses mempersiapkan hal-hal yang akan dikerjakan pada waktu yang akan datang untuk mencapai suatu tujuan yang telah ditetapkan [8]. Pada tahap perencanan siklus I dilaksanakan pada tanggal 3-4 April 2016 peneliti dan kolaborator merencanakan pelaksanaan pembelajaran yang akan dilaksanakan ketika proses pembelajaran yaitu dengan rencana pelaksanaan pembelajaran (RPP) yang meliputi merencanakan bahan ajar dan merumuskan tujuan, merencanakan pengorganisasian materi ajar, merencanakan skenario langkah-langkah pembelajaran, memilih sumber dan media, merencanakan evaluasi pembelajaran.

\section{Tindakan (Acting)}

Pada tahap tindakan siklus I dilaksanakn pada hari Rabu dan Kamis pada tanggal 6-7 April 2016, dengan alokasi waktu $2 \times 40$ menit dengan dua pertemuan.

\section{Pengamatan (Observing)}

Pengamatan Terhadap Kemampuan Guru Merencanakan Pembelajaran (APKG 1) Siklus I

Setelah peneliti melakukan pengamatan terhadap perencanaan pembelajaran yang dilakukan dari 28 aspek yang dinilai terdapat 5 aspek dengan kriteria sangat baik dengan persentase $17,85 \%$, terdapat 13 aspek dengan kriteria baik dengan persentase $46,42 \%$, terdapat 9 aspek baik dengan persentase $32,14 \%$, terdapat 1 aspek kriteria kurang baik dengan persentase $3,57 \%$ dari keseluruhan total pemerolehan skor mencapai 72,85 termasuk dalam kategori cukup baik.

Pengamatan Terhadap Kemampuan Guru Melaksanakan Pembelajaran (APKG 2) Siklus I

Setelah peneliti melakukan pengamatan pembelajaran didalam kelas dan menilai pelaksanaan pembelajaran yang dilakukan dari 49 aspek yang dinilai mengenai pembelajaran yang dilakukan menulis rangkuman menggunakan model pembelajaran cooperative integrated readig and composition terdapat 13 aspek kategori sangat baik dengan persentase $26,53 \%$, terdapat 19 aspek dengan kategori baik dengan persentase $38,77 \%$, terdapat 15 aspek dengan kategori cukup baik dengan persentase $30,61 \%$, terdapat 2 aspek kategori kurang baik dengan persentase 4,08 \%. Dari keseluruhan pemerolehan skor persetase kemampuan guru dalam melaksanakan pembelajaran (APKG 2) setelah dilakukan pengamatan mencapai $77,75 \%$ dari 49 aspek termasuk dalam kategori baik.

Pengamatan terhadap Sikap Siswa Dalam Pembelajaran Menulis Rangkuman Menggunakan Model Cooperative Integrated Reading and Composition
Aspek menggunakan bahasa Indonesia yang baik dan benar dengan skor 5 sebanyak 13 siswa dengan skor $(38,23 \%)$, siswa dengan skor 4 sebanyak 16 siswa dengan skor $(47,05 \%)$ siswa dengan skor 3 sebanyak 4 siswa $(11,76 \%)$, siswa dengan skor 2 sebanyak 1 siswa $(2,94 \%)$, siswa dengan skor 1 sebanyak 0 siswa (0\%). Aspek kesungguhan dengan skor 5 sebanyak 11 siswa dengan skor $(32,35 \%)$, siswa dengan skor 4 sebanyak 15 siswa dengan skor $(44,11 \%)$, siswa dengan skor 3 sebanyak 8 siswa dengan skor $(23,52 \%)$, siswa dengan skor 2 sebanyak 0 siswa $(0 \%)$, siswa dengan skor 1 sebanyak 0 siswa $(0 \%)$. Aspek kerjasama kelompok dengan skor 5 sebanyak 11 siswa $(32,35 \%)$, siwa dengan skor 4 sebanyak 15 siswa $(44,11 \%)$, siswa dengan skor 3 sebanyak 6 siswa $(17,64 \%)$, siswa dengan skor 2 sebanyak 2 siswa $(5,88 \%)$ siswa dengan skor 1 sebanyak 0 siswa $(0 \%)$.

\section{Refleksi (Reflecting)}

Refleksi Terhadap Perencanaan

Dalam rencana pelaksanaan pembelajaran (RPP), sebagian besar aspek yang dinilai sudah mencapai kategori baik namun masih ada hal-hal yang perlu diperbaiki seperti berikut. (1) Guru harus memberikan umpan balik kepada siswa tentang cara yang mudah dalam menemukan gagasan utama. (2) Guru harus menyiapkan bahan pembelajaran secara rinci dan sesuai dengan materi pembelajaran. (3) Membuat rencana evaluasi untuk mengukur keberhasilan pembelajaran.

Refleksi Terhadap Pelaksanaan

Refleksi terhadap tahap pelaksanaan dalam rencana pelaksanaan pembelajaran (RPP), sebagian besar aspek yang dinilai sudah mencapai kategori baik namum masih ada halhal yang harus diperbaiki sebagai berikut. (1) Pada kegiatan pembelajaran guru masih kurang maksimal dalam merangsang partisipasi siswa untuk mengikuti proses pembelajaran. (2) Pada pendekatan pembelajaran guru tudak runtut dalam pelaksanaan pembelajaran, sebaiknya guru dalam melaksanakan pembelajaran secara runtut sehingga hasil yang didapatkan siswa maksimal. (3) Pada pelaksanaan pembelajaran guru dan siswa tidak membuat kesimpulan terhadap proses pembelajaran, sebaiknya guru menyimpulkan pembelajaran agar dapat menjadi penguatan materi terhadap siswa. (4) Dalam membentuk kelompok guru tidak membimbing siwa agar pembelajaran menjadi tidak ribut.

\section{Hasil Peniaian Proses Menulis Rangkuman Menggunakan Model Cooperative Integrated Reading and Composition Siklus I}

Pada hasi proses pembelajaran menulis rangkuman untuk siklus I siswa yang kurang sekali dalam pencapiannya sebanyak 2 siswa dengan persentase $5,88 \%$, siswa yang pencapaiannya kurang sebanyak 1 siswa dengan persentase $2,94 \%$, siswa yang pencapaiannya cukup sebanyak 12 siswa dengan persentase $35,29 \%$, siswa yang pencapaiannya baik sebanyak 11 siswa dengan persentase $32,35 \%$, siswa yang pencapaiannya sangat baik sebanyak 6 siswa dengan 
persentase $23,52 \%$ dan jumlah siswa yang tuntas sebanyak 22 siswa dengan persentase 64,70\%, sedangkan jumlah siswa yang tidak tuntas sebanyak 12 siswa dengan persentase $35,29 \%$. Ketuntasan menulis rangkuman secara individu mencapai $64,70 \%$.

\section{Deskripsi Hasil Penelitian Siklus II}

Perencanaan Untuk Meningkatkan Keterampilan Menulis Rangkuman Menggunakan Model Cooperative Integrated Reading and Composition Siklus II

Pada tahap perencanaan dalam kegiatan pembeajaran menulis rangkuman peneliti dan kolaborator salng bekerjasama untuk menyusun kegiatan proses belajar mengajar yang dilaksanakan pada tanggal 11-12 April 2016.

\section{Pelaksanaan Pembelajaran Menulis Ragkuman Menggunakan Model Pembelajaran Cooperative Integrated Reading and Composition Siklus II \\ Pada tahap perencanaan siklus I dilaksanakan pada tanggal 11-12 April 2016 peneliti dan kolaborator merencanakan pelaksanaan pembelajaran yang akan dilaksanakan ketika proses pembelajaran yaitu dengan rencana pelaksanaan pembelajaran (RPP) yang meliputi merencanakan bahan ajar dan merumuskan tujuan, merencanakan pengorganisasian materi ajar, merencanakan skenario langkah-langkah pembelajaran, memilih sumber dan media, merencanakan evaluasi pembelajaran.}

\section{Perencanaan}

Pada tahap perencanaan siklus I dilaksanakan pada tanggal 27 Februari 2016 peneliti dan kolaborator merencanakan pelaksanaan pembelajaran yang akan dilaksanakan ketika proses pembelajaran yaitu dengan Rencana Pelaksanaan Pembelajaran (RPP) yang meliputi merencanakan bahan ajar dan merumuskan tujuan, merencanakan pengorganisasian materi ajar, merencanakan skenario langkah-langkah pembelajaran, memilih sumber dan media, merencanakan evaluasi pembelajaran.

\section{Tindakan (Acting)}

Pada tahap tindakaan siklus II dilaksanakan pada tanggal 13-14 April 2016, dengan alokasi waktu 2 x 40 menit dengan dua pertemuan.

\section{Pengamatan (Observing)}

Pengamatan Terhadap Kemampuan Guru Merencanakan Pembelajaran (APKG I) Siklus II

Setelah peneliti melakukan pengamatan didalam kelas dan menilai perencanaan pembelajaran yang dilakukan dari 28 aspek yang dinilai terhadap kemampuan guru dalam merencanakan pembelajaran menulis rangkuman yaitu 13 aspek kriteria sangat baik dengan persentase 46,42\%, 12 aspek kriteria baik dengan persentase 42,85 \%, 3 aspek kriteria cukup baik dengan persentase 10,17 \% dari keseluruhan total pemerolehan tiap skor mencapai persentase $87,14 \%$ termasuk dalam kategori sangat baik.
Pengamatan terhadap Kemampuan Guru dalam melaksanakan Pembelajaran (APKG 2) Siklus II

Setelah peneliti melakukan pengamatan didalam kelas dan menilai pelaksanaan pembelajaran yang dilakukan dari 49 aspek yang dinilai mengenai perencanaan pembelajaran menulis rangkuman menggunakan model cooperative integrated reading and composition terdapat 23 aspek kriteria sangat baik dengan persentase 46,93\%, 22 aspek kriteria cukup dengan persentase 47,89 \%, 3 aspek kriteria cukup baik dengan persentase $6,12 \%$ dan 1 aspek dengan kriteria kurang dengan persentase 2,04 \% dan dari keseluruhan total pemerolehan skor mencapai 88,97\% termasuk dalam kategori sangat baik.

Pengamatan terhadap Sikap siswa dalam pembelajaran menulis rangkuman menggunakan model pembelajaran Cooperative Integrated Reading and Composition

Aspek menggunakan bahasa Indonesia yang baik dan benar 22 siswa mampu menyampaikan informasi kepada teman satu kelompoknya menggunakan bahasa indonesia yang baik dan benar, 10 siswa mendapat skor baik karena dalam menyampaikan informasi kepada teman satu kelompoknya sekali-sekali menggunakan bahasa daerah, 1 siswa kadang-kadang menggunakan bahasa daerah dalam menyampaikan informasi. Aspek kesungguhan 24 siswa mendapat nilai sangat baik karena pada saat mengerjakan tugas sangat bersungguh-sungguh, 8 siswa mendapat nilai baik karena dalam mengerjakan tugas sesekali bergurau dengan temannya dan 1 siswa mendapat nilai cukup baik karena pada saat pembelajaran tidak mengerjakan tugas dengan serius. Aspek kerjasama kelompok10 mendapat nilai sangat baik karena pada saat berdiskusi sangat kompak bekerja bersama kelompoknya, 23 siswa mendapat nilai baik karena ada sesekali tidak kompak, 10 siswa mendapat nilai cukup baik karena dalam mengerjakan tugas bersama teman satu kelompoknya kadang tidak kompak dan 1 siswa mendapat nilai kurang baik karena lebih banyak mengerjakan sendiri dibandingkan bekerja bersama kelompoknya.

\section{Refleksi (Reflection)}

Refeksi Terhadap Perencanaan

Dalam rencana pelaksanaan pembelajaran (RPP), sebagian besar aspek yang dinilai sudah mencapai kategori baik namun masih ada hal-hal yang perlu diperbaiki seperti berikut. (1) Menetukan alokasi waktu, (2) Menentukan media pembelajaran, (3) pedoman penilaian.

Refleksi Terhadap Pelaksanaan

Dalam rencana pelaksanaan pembelajaran (RPP), sebagian besar aspek yang dinilai sudah mencapai kategori sangat baik.

\footnotetext{
Hasil Penilaian Pada Proses Pembelajaran Menulis Rangkuman Menggunakan Model Pembelajaran Cooperative Integrated Reading and Composition Siklus II

Hasil proses pembelajaran menulis rangkuman untuk siklus II terdapat 17siswa dengan kriteria sangat baik dengan persentase $51,51 \%$, terdapat 11 siswa dengan kriteria baik
} 
dengan persentase $33,33 \%$, terdapat 1 siswa dengan kriteria cukup baik dengan persentase 3,03\%, 1 siswa dengan kriteria kurang baik dengan persentase $3,03 \%$, terdapat 3 siswa dengan kriteria sangat kurang dengan persentase $9,09 \%$

\section{PEMBAHASAN}

Perencanaan pembelajaran yang sudah disusun dari siklus I sampai siklus II mengalami peningkatan.Perencanaan pembelajaran yang disusun sudah sesuai dengan kriteria penilaian.Peningkatan itu dapat dilihat pada tabel berikut.

Tabel 1

Peningkatan Kemampuan Guru Merencanakan Proses Pembelajaran

\begin{tabular}{|c|c|c|c|c|}
\hline No & Keterangan & Siklus 1 & Siklus 2 & Peningkatan \\
\hline $\mathbf{1}$ & APKG 1 & $72,85 \%$ & $87,14 \%$ & $14,29 \%$ \\
\hline
\end{tabular}

\section{Ketuntasan Proses Belajar Menulis Rangkuman Menggunakan Model Pembelajaran Cooperative Integrated Reading and Composition Siklus 1 dan Siklus 2}

Tabel 2

Ketuntasan Proses Belajar Menulis Rangkuman Menggunakan Model Pembelajaran Cooperative Integrated Reading and Composition Siklus 1 dan Siklus 2

\begin{tabular}{|c|c|c|c|c|c|c|}
\hline \multirow[t]{2}{*}{ No } & \multirow[t]{2}{*}{ Ket } & \multirow{2}{*}{$\begin{array}{c}\text { Jmlh } \\
\text { Siswa }\end{array}$} & \multicolumn{2}{|c|}{ Nilai } & \multirow{2}{*}{$\begin{array}{c}\text { Rata- } \\
\text { rata }\end{array}$} & \multirow{2}{*}{$\begin{array}{c}\text { Ketunta } \\
\text { san } \\
\text { Belajar }\end{array}$} \\
\hline & & & Tuntas & $\begin{array}{l}\text { Tidak } \\
\text { Tuntas }\end{array}$ & & \\
\hline 1 & Siklus 1 & 34 & $\begin{array}{c}21 \\
\text { siswa } \\
(61,76 \\
\%)\end{array}$ & $\begin{array}{c}13 \text { siswa } \\
(38,23 \\
\%)\end{array}$ & 77 & $61,76 \%$ \\
\hline 2 & Siklus 2 & 33 & $\begin{array}{c}29 \\
\text { siswa } \\
(87,87 \\
\%)\end{array}$ & $\begin{array}{l}14 \text { siswa } \\
(14,14 \\
\%)\end{array}$ & 82,18 & $87.87 \%$ \\
\hline
\end{tabular}

\section{SIMPULAN DAN SARAN}

\section{SIMPULAN}

Berdasarkan analisis data dan hasil yang dilakukan dengan dua siklus dapat disimpulkan bahwa model pembelajaran Cooverative Integrated Reading and Composition dapat meningkatkan keterampilan menulis rangkuman siswa kelas VIII B SMP Negeri 8 Singkawang. Secara khusus uraian mengenai hasil pembahasan penelitian tindakan kelas yang dapat disimpulkan sebgai berikut. Perencanaan pembelajaran dengan menggunakan model pembelajaran Cooverative Integrated Reading and Composition pada siswa kelas VIII B SMP Negeri 8 Singkawang, pada siklus I mencapai 72,85 termasuk dalam kategori cukup baik, sedangkan pada siklus II mengalami peningkatan yaitu mencapai $87,14 \%$ yang termasuk dalam kategori sangat baik mengalami peningkatan sebesar 14, $29 \%$. Pelaksanaan pembelajaran menggunakan model Cooverative Integrated Reading and Composition pada kelas VIII B SMP Negeri 8 Singkawang dapat meningkatkan hasil pembelajaran menulis rangkuman. Hal ini dapat dibuktikan pada saat guru mata pelajaran bahasa Indonesia melaksanakan kegiatan pembelajaran. Kinerja guru dalam mengelola pembelajaran terus meningkat dari $77,55 \%$ pada siklus I dan siklus II mencapai $88,97 \%$ berarti mengalami peningkatan sebesar $11,42 \%$. Hasil pembelajaran menggunakan model Cooverative Integrated Reading and Composition pada meteri menulis rangkuman. Rata- rata hasil belajar yang didapatkan siswa kelas VIII B SMP Negeri 8 Singkawang dalam mengikuti pembelajaran menggunakan model Cooverative Integrated Reading and Composition mengalami peningkatan. Pada siklus 1 siswa yang tuntas hanya mencapai 22 siswa sedangkan yang tidak tuntas masih mencapai 12 siswa dengan ketuntasan hanya mencapai $64,70 \%$, sedangkan pad siklus II siswa yang tuntas mencapai 29 siswa dan tidak tuntas hanya 4 siswa, ketuntasan pada siklus II mencapai $87,87 \%$. Terjadi peningkatan nilai rata-rata sebesar $23,17 \%$.

SARAN

Guru mata pelajaran bahasa Indonesia dapat menggunakan model Cooverative Integrated Reading and Composition untuk meningkatkan kemampuan siswa dalam membaca dan menulis dalam kegiatan pembelajran dengan benar. Guru sebaiknya bersama siswa membicarakan sampai seberapa jauh pemahaman siswa tentang materi pembelajaran yang dibahas. Bila sebagian besar siswa tersebut tidak memahami apa yang dibahas, sebaiknya guru membicarakan ulang materi pembelajaran bersama-sama dalam kelas. Jika hanya sebagian besar siswa saja yang tidak memahami meteri pembelajaran, bantuan secara individual atau kelompok kecil perlu diberikan oleh guru kepada siswa tersebut. Pada saat proses pembelajaran siswa sebaiknya mendengarkan dan memperhatikan penjelasan guru dan belajar dengan sungguh-sungguh sehingga hasil yang didapatkan siswa pada saat proses pembelajaran dapat ditingkatkan. Pada saat membentuk kelompok belajar dalam kelas, hendaknya guru memiliki teknik khusus tersendiri dalam membentuk kelompok agar pembelajaran lebih efektif dan efisien.

\section{DAFTAR PUSTAKA}

[1] Tarigan, Henry Guntur.. 1986. Teknik Pengajaran Keterampilan Berbahasa. Bandung: Penerbit Angkasa

[2] Eduka, Tim Guru 2012. Mega Bank Soal Bahasa Indonesia. Jakarta: Cmedia. 
[3] Rusman. 2014. Model Model Pembelajaran. Jakarta: Rajawali Pers.

[4] Kosasih, E. 2010. Pendekatan Metode dan Teknik Pembelajaran Bahasa Indonesia. Bandung: Genesindo.

[5] Slavin, Robert E. 2005. Cooperative Learning. Bandung: Nusa Media.

[6] Tarigan, Henry Guntur. 2008. Menulis Sebagai Suatu Keterampilan Berbahasa. Bandung: Angkasa Bandung.

[7] Moleong, Lexy J. 2013. Metode Penelitian Kualitatif. Bandung: Remaja Rosadakarya.

[8] Ramayulis. 2013. Profesi dan Etika Keguruan. Jakarta: Kalam Mulia.

[9] Tarigan, Henry Guntur. 2008. Menulis Sebagai Suatu Keterampilan Berbahasa. Bandung: Angkasa Bandung.

[10] Asrori, Muhamad. 2009. Penelitian Tindakan Kelas. Bandung :Wacana Prima. 